\title{
DECLINING IMPORTANCE OF TRILOBITES IN ORDOVICIAN NEARSHORE COMMUNITIES: DISPLACEMENT OR DILUTION?
}

WESTROP*, Stephen R., Dept. of Geological Sciences, Brock University, St. Catharines, Ontario L2S 3A1, Canada; TREMBLAY, James V., Dept. of Geology, McMaster University, Hamilton, Ontario L8S 4M1, Canada; LANDING, Ed, New York State Geological Survey, State Education Dept., Albany, NY 12230, U.S.A.

Declining importance of trilobites was a key feature of Ordovician community "evolution". Previous work has shown that replacement of trilobite-dominated communities by mollusc- and brachiopod-dominated communities was diachronous, occurring initially in nearshore settings. The processes responsible for these changes remain unclear, although many previous discussions have invoked some form of displacement of dominants of one community by those of another.

New data from more than thirty large collections made from nearshore facies at five localities in Canada and the northern United States indicate that, in this setting, trilobite species diversity maintained a constant low level (mean and mode of 3 species) between the Early Upper Cambrian (Marjuman) and the Late Middle Ordovician (Blackriveran). Reorganization of nearshore communites proceeded by addition of new elements, especially molluscs, from the Late Cambrian (Sunwaptan) onwards. Decline in the relative importance of trilobites was a case of dilution as species of new clades accumulated, rather than actual displacement. Trilobites appear to have been passive bystanders in Ordovician nearshore community "evolution". Towards the end of the Ordovician, trilobites vacated nearshore environments in the Appalachian region. However, this appears to be related to environmental changes associated with progradation of clastic wedges during the development of the Taconic foreland basin.

A process of dilution may at least partly explain the offshore retreat of trilobitedominated assemblages during the Ordovician. Offshore trilobite assemblages reached much greater species diversity than those of nearshore settings, so that their dilution via the addition of species of newly radiating clades would have proceeded more slowly. That is, trilobite-dominated paleocommunities may have persisted into the Ordovician in the outer shelf simply because this was the region in which, historically, they attained maximum species richness. Moreover, given the existence of a general pattern of increasing total species diversity of communities from nearshore to offshore sites, the tendency for newly radiating clades to attain maximum species richness offshore is not surprising: they are merely conforming to a general, environmentallyrelated diversity gradient that has existed throughout the Phanerozoic. 